\title{
Impact of Coastal Erosion and Tidal Flood to Land Loss at Sriwulan Village, Sayung, Demak, Central Java Province
}

\author{
Chatarina Muryani \\ Geography Education Study Program \\ Sebelas Maret University \\ Surakarta, Indonesia \\ Coresponding email: chatarinamuryani@ymail.com \\ Setya Nugraha \\ Geography Education Study Program \\ Sebelas Market University \\ Surakarta, Indonesia \\ Singgih Prihadi \\ Geography Education Study Program \\ Sebelas Market University \\ Surakarta, Indonesia
}

\begin{abstract}
This study was aimed to (1) determine the hazard level of coastal erosion and tidal flood, (2) total land loss due to coastal erosion and tidal flood, (3) the people perception against coastal erosion and tidal flood disaster in Sriwulan village, Sayung Sub-district, Demak, Central Java Province. The study was conducted by analyzing and overlapping maps, observing the field and interviewing the residents. The results showed that (1) most of the Sriwulan village was inundated by tidal flood every day from a few centimeters to more than 1 meter, (2) during the period of 2003 to 2016 there had been 60 hectares land loss, consisted of 51 hectares of fishpond and 9 hectares of settlement, (3) residents were disturbed by the coastal erosion and tidal flood; however, the government had not taken any concrete moves toward these problems yet.
\end{abstract}

Keywords — coastal erosion, tidal flood, land loss, perception.

\section{INTRODUCTION}

Indonesian coastal has a large resource potential. According to Dahuri (2001), the potential of coastal resources are generally divided into four groups: (1) renewable resources, (2) non-renewable resources, (3) marine energy and (4) environmental services. Consequences of the use of coastal and marine resources as public property resource is an increasing of coastal and marine natural resources use in almost all areas. This utilization tends to exceed the carrying capacity of the resources (Stanis et.al, 2007).

Today the coastal areas and communities facing the growing threat to their environment health, including habitat loss, water pollution and the impact of climate change
(Nichols, et. al., 2010). One of the threats in coastal areas is the reduction in land area due to tidal flood and abrasion.

Coastal environments are in a dynamic relationship with the sea. By the sand and soil constantly shifting, it creates new shorelines or eroding others. The rising of sea level exacerbates erosion, disturbs human activities, and breaks building construction, roads, and seawalls, and changes the natural lands, marshes and dunes migration. As a result, shorelines erode and increase the threat to coastal development and infrastructure (Briguglio, 2004)

The rising of sea-level causes coastal inundation and erosion which gives great effects to the economy and ecology, considering the intensive and irreversible changes which most likely occur in the coastal ecosystems (Demirkesen et. al., 2006)

One of the coastal villages which are threatened by coastal erosion and tidal flood is Sriwulan Village, Sayung, and Demak District. Every year, there is about $10 \%$ of the population who has to move from their residence due to their homes were flooded, damaged, and not habitable anymore (Tribune Jawa, Mei, 2016). According to Zamroni (head village of Sriwulan), during 2016, almost every day there are people who have asked for a permision to move. He also explained that the road linking Sriwulan, Bedono, Timbul sloko villages, and towards Sub Genuk were gone drowned. 
This study was aimed to determine the land loss in Sriwulan village, Sayung Sub-district, Demak district, and the perception of the population about the abrasion, and tidal flood disaster at the village.

\section{METHOD}

The research on the impact of coastal erosion and tidal flooding in Sriwulan village was done through the following steps:

- Analysis of IKONOS imagery from Google Earth time series, years 2003, 2007, 2012 and 2016 (based on imagery available). The overlay result of land use image analysis and the coastline maps in 2003, 2007, 2012, 2016 produced maps of land use change and shoreline change from 2003 to 2016. From the land use change and shoreline change, it could be analyzed the land loss in the study area.

- Field observations were done by (a) field testing based on the results of image analysis in key location, and (b) direct observation of coastal abrasion and tidal flood and their impact on the physical and social aspect.

- Interview with the affected people.

Interview with the affected population was done to determine their perception of coastal erosion and tidal flood. Research sampling was determined by proporsive sampling, limitted to the population who were directly affected by tidal flood and loss their land or homes. Interviews were conducted in Nyangkringan village, because Nyangkringan village is the most affected by coastal erosion and tidal flood.

\section{FINDING AND DISCUSSION}

\section{A. Discription of research area}

Sriwulan is one of the villages in the Sayung District. This coastal village is located directly adjacent to Semarang city. Administratively Sriwulan village consists of four hamlets (Pututan, Sidomukti, Sriwulan, Nyangkringan) and RadenPatah Housing. The area is also traversed by two rivers, the Babonriver, and the Menyong River. This area has a flat topography, altitude between 0-7 meters from the sea level.

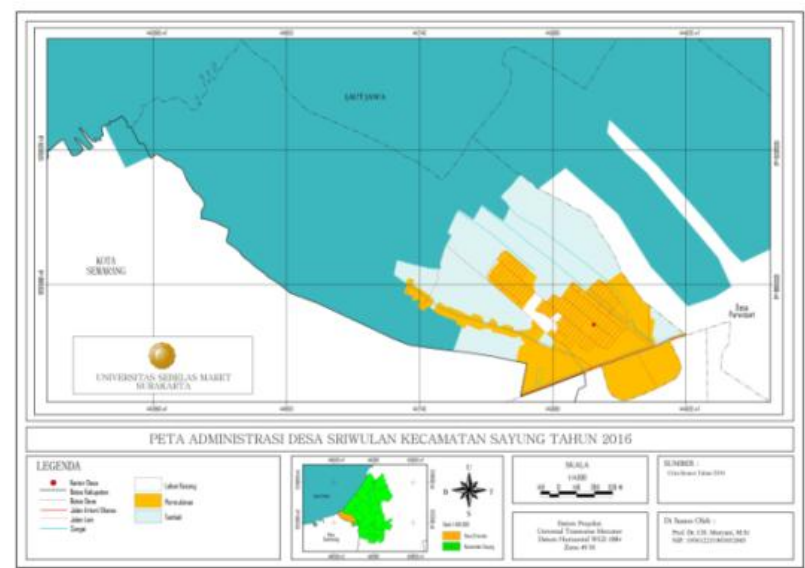

Fig. 1. The location Sriwulan Village

\section{B. The inundation of research area}

Initially, Sriwulan is an agricultural village. Some of the residents are farmers and fishermen. There are 250 hectares of rice fields, but much of the land is not cultivable anymore due to the impact of erosion and tidal flood, which then converted and utilized as fishpond by the community, especially milkfish and shrimp (RPDP Sriwulan, 2013). Coastal reclamation in Semarang city and the high sedimentation of Babon River thought to be one cause of the high coastal erosion and tidal inundation in District Sayung, including Sriwulan village. The intensity of abrasion and tidal inundation progressively increase and fear the faster land loss.

In the research area the paddy fields have turned into fishponds, while the former fishponds that have been permanently inundated turned into part of the sea. Fishponds that are still functioning are in alarm condition because the higher the inundation the higher cost to install nets around it.

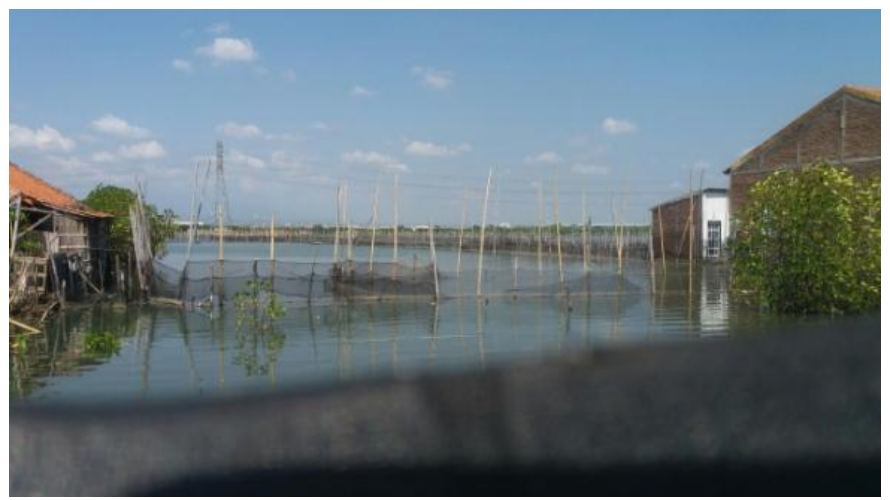

Fig. 2. Fishpond condition in research area

At the time of the study, i.e. in August 2016, almost the entire Sriwulan area is daily inundated by tidal flood to a depth that varies from a few centimeters to about 1 meter. Based on field observations and interviews with residents, the tidal flood and coastal erosion in the Sriwulan village have eliminated most fishponds, destroyed and flooded houses so there had to be abandoned, ruined the environment, hampered economic activities of the society, damaged roads and other infrastructure.

Residents have issued a large cost to lift the house floor so that water did not enter the house, but it only lasted for a few months since the water keep flooded their homes because of the increasing intensity of the tidal flood. Residents who cannot tolerate these conditions choose to move to another place and leave their homes.

The families who stay in the study area have no other choice but adapting to the waterlogged conditions every day. Some families whose homes were flooded quite high, providing boats for mobilization. 


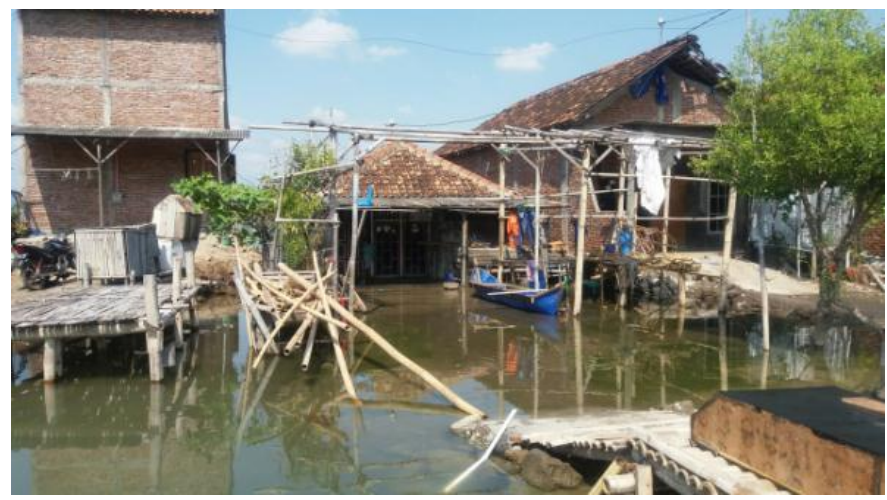

Fig. 3. Tidal flooding adaptation with higher the house and providing boats

\section{Land use Change}

Abrasion and tidal flood frequency were increasing continuously, so the land area in Sriwulan village is narrowing.

IKONOS imagery interpretation results from Google earth of 2003, 2007, 2012 and 2016showed the land use and shoreline maps of Sriwulan village years 2003, 2007, 2012 and 2016. The land use of Sriwulan village from 2003 to 2016 is as follows:

TABLE I: LAND USE OF SRIWULAN VILLAGE YEARS 2003, 2007, 2012, AND 2016

\begin{tabular}{|c|c|c|c|c|}
\hline Land use & $\begin{array}{c}\text { year 2003 } \\
\mathrm{Ha} / \%\end{array}$ & $\begin{array}{c}\text { year 2007 } \\
\mathrm{Ha} / \%\end{array}$ & $\begin{array}{c}\text { year 2012 } \\
\mathrm{Ha} / \%\end{array}$ & $\begin{array}{c}\text { year } 2016 \\
\mathrm{Ha} / \%\end{array}$ \\
\hline Settlement & $86 / 37,2$ & $85 / 39,5$ & $85 / 44$ & $77 / 45$ \\
\hline Fishpond & $142 / 61,5$ & $127 / 59,1$ & $105 / 54,4$ & $91 / 53,2$ \\
\hline Bare land & $3,0 / 1,3$ & $3,0 / 1,4$ & $3,0 / 1,6$ & $3,0 / 1,8$ \\
\hline
\end{tabular}

Based on the image interpretation above, compared with the field observation and deep interview with local residents result, it is obtained the fact that there was significant land use change in the study area.

\section{- Settlement}

Based on image analysis, land used as a settlement in Sriwulan village in 2003 was 86 hectares. From 2003 to 2007, land settlement reduced by 1 hectare (from 86 ha to 85 ha), from 2007 to 2012, land used as settlement remains, whereas from 2012to 2016 land settlement was reduced by 8 hectares (from 85 ha to 77 ha). Between the years 2003 up to year 2016 settlement area in the study area was reduced by 9 hectares.

Based on field observations the loss of settlement area was far more than the image analysis. Many houses are still standing, but abandoned because the land is permanently waterlogged and deep enough so that everyday activities was disrupted and harmful for the family. But there are also families who remained in the study area even though their houses were inundated because they have no other alternative.

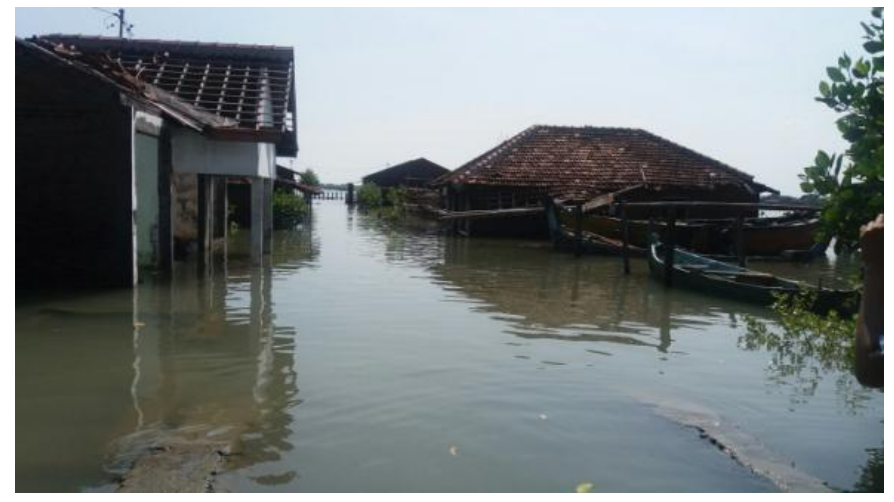

Fig. 4. The houses were abandoned, but still visible as a settlement in the image analysis

The houses which were permanently flooded and no longer habitable were still visible on the image and interpreted as a settlement, so that in reality the reduction of residential land is more than the results of image interpretation.

\section{- Fishpond}

Based on the result of Indonesian visual image of 2000, fishponds in the study area were originally paddy field, both tidal paddy and rained paddy. Based on the information given by the local residents, since the land is frequently flooded, it then converted into a fishpond. Due to the process of coastal erosion and inundation by tidal flood, a lot of ponds did not work any longer and turned into the sea. Fishpond that is still used now is also threatened its existence.

Based on the image analysis, it showed that there was a significant reduction of fishpond area in the study area. Between 2003 and 2007 the fishpond area is reduced 15 hectares (142 ha to 127 ha), between 2007 and 2012 fishpond area was reduced by 2 hectares (from 107 hectares to 105 hectares), between 2012 to 2016 land area used as pond reduced 14 hectares (105 hectares 91 hectares). Overall from 2003 to 2016, the fishpond area in the study area decreased 51 hectares.

\section{- Bare land}

For the research, areas called as bare land is land usage besides fishponds and settlements, such as cemeteries, roads, courts, and others. The bare land in the study area is relatively fixed, about 3 hectares. Based on field observation, many public facilities in Sriwulan village have been damaged due to frequently inundated by salty water, such as roads, sports grounds, cemeteries, etc.

From image analysis, the whole land loss in research area between 2003 and 2016 (13 years) was 60 hectares, consists of 51 hectares of fishponds and 9 hectares of settlements. Based on the reality, land loss was more than counted in the image since there were many houses that had been abandoned but were still counted as a settlement. The average land loss due to coastal erosion and tidal flooding in the research area was 5 hectares per year. The area most severely affected by abrasion and tidal flood is Nyangkringan. Nyangkringan was also the 
hamlet which was most left by their residents. Hence the intensity of the threat of erosion and tidal flood was higher from year to year, land loss due to coastal erosion and tidal flood will increase and it is an open possibility that one time Sriwulan village will wholly sink.

\section{People Perception}

According to interviews with the tidal flood affected the population in the study area (9 head of family at Nyangkringan hamlet, village Sriwulan), it was found the following realities:

- Abrasion and tidal flood have brought losses to the population both for their loss of land and livelihood. Tidal flood which came into the houses and pooled on the street and the yard had destroyed infrastructure, household appliances and many others. Tidal flood also disrupts economic activities.

- Residents accepted the natural phenomena, abrasion and tidal flood, as a fate that must be experienced. They did not blame any parties on this incident.

- There was lack of government attention to the victims of abrasion and tidal flood.

- There was lack of any real action from the government and other parties.

- Residents who did not move since the house was the only property they have, they do not know where to move.

\section{CONCLUSIONS AND SUGGESTIONS}

\section{A. Conclusion}

From the data and data analysis, it could be concluded that: In the area of research, there has been going on abrasion and tidal flood that resulted in the loss of land for at least 60 hectares during 2003 to 2016, consisted of the loss of residential land area of 9 hectares and the loss of fishpond area of 51 hectares.

There was no serious action from the government to defend erosion and tidal flood in the area of research, and the population considered the occurrence of abrasion and rob in the area as a natural phenomenon and not blame other parties.

\section{B. Suggestion}

Abrasion and tidal flood condition in Sriwulan village is very worrying, the government should immediately take definite action to rescue the residents. The government of Demak regency needs to give land facilities for the people whose houses were damaged by abrasion and tidal flood to move in. People needs to have initiative, either individually or in groups to prevent the occurrence of abrasion and tidal flood based on local wisdom.

\section{REFERENCES}

[1] Briguglio, 2014, "A Vulnerability and Resilience Framework for Small States", Report prepared for the Commonwealth Secretariat, University of Malta.

[2] Dahuri, R., Rais, Y., Putra, S.G., Sitepu, M.J., 2001, "Pengelolaan Sumber Daya Wilayah Pesisir dan Lautan secara Terpadu”, Pradnya Paramita, Jakarta.
[3] Demirkesen A.C, Evrendilek F.,.Berberoglu S and Kilic S, (2006), "Coastal Flood Risk Analysis Using Landsat-7 ETM+ Imagery and SRTM DEM: A Case Study of Izmir", Turkey, Environ Monit Assess, DOI 10.1007/s10661-006-9476-2.

[4] Nichols B, Jessica H.K., Brian B, (2010), Community Based Management of Coastal Ecosystems, California, Oregon, Washington, West Cost EBM Network.

[5] Pemerintah Kabupaten Demak, Kecamatan Sayung, Desa Sriwulan, (2013), Rencana Pengembangan Desa Pesisir.

[6] Stanis Stefanus, Supriharyono, dan Azis Nur Bambang, (2007), Pengelolaan Sumberdaya Pesisir dan Laut Melalui Pemberdayaan Kearifan Lokal di kabupaten Lembata Propinsi Nusa Tenggara Timur, Jurnal Pasir Laut, $2.2: 67$ - 82.

[7] Tribun Jateng, 2016, Sriwulan tenggelam, ketinggian Rob di Demak capai 1 meter, http://jateng.tribunnews.com, accessed on August 5, 2016. 